\title{
Klasifikasi Cacat Lintasan Dalam Bantalan Bola Berbasis Support Vector Machine (SVM) pada Fan Industri
}

\author{
(Classification of Inner Race Fault of the Ball Bearing Based on Support Vector Machine (SVM) \\ for Industrial Fan) \\ BERLI P KAMIEL, ARIE JOKO WIRANTO, BAMBANG RIYANTA
}

\begin{abstract}
ABSTRAK
Fan adalah sebuah mesin industri yang berfungsi mensirkulasikan udara di dalam sebuah ruangan. Salah satu komponen dari fan yang sering rusak adalah bantalan. Metode spektrum merupakan salah satu metode deteksi rusak/cacat bantalan berbasis getaran yang umum digunakan namun grafik spektrum sering sulit dipahami oleh operator di lapangan. Metode pengenalan pola (pattern recognition) adalah metode yang mudah digunakan karena tidak perlu menterjemahkan grafik spektrum. Metode pengenalan pola yang digunakan pada penelitian ini adalah Support Vector Machine (SVM). Tujuan penelitian ini adalah mendeteksi cacat lintasan dalam pada bantalan bola. Penelitian ini menggunakan dua kondisi bantalan yang berbeda yaitu bantalan normal, dan bantalan cacat. Cacat pada bantalan dibuat dengan metode Electrical Discharge Machine (EDM) pada lintasan dalam dengan kedalaman 1,4 $\mathrm{mm}$ dan lebar 0,4 $\mathrm{mm}$. Sinyal getaran bantalan direkam dari rig uji fan industri menggunakan software MATLAB dengan merekam data sebanyak 700 file untuk setiap kondisi. Data tersebut diektraksi kedalam 17 parameter statistik yang kemudian diseleksi secara visual sebagai input SVM. Klasifikasi SVM dilakukan dengan variasi kernel Radial Basis Function (RBF), Polynomial dan Linear. Hasil penelitian menunjukkan parameter statistik entropy dengan standart error menggunakan variasi kernel Radial Basis Function (RBF), Polynomial dan Linear adalah rekomendasi untuk klasifikasi cacat pada bantalan lintasan dalam karena menghasilkan akurasi sebesar $100 \%$.
\end{abstract}

Kata kunci: kernel function, parameter statistik, pengenalan pola, spektrum.

\section{ABSTRACT}

Industrial fan is one of -rotating machinery commonly used by industries to circulate air in a particular area. One of the most important component of a fan is the bearing which may fault during its operation Spectrum analysis is one of vibration-based methods frequently used to detect faulty bearing but this method has a disadvantage that is not easily understood by operators in the field. Pattern recognition method is an easy method to be used because it does not need to interpret the spectrum. The pattern recognition method used in this study is Support Vector Machine (SVM). The purpose of this study is to detect inner race fault of a ball bearing using SVM. This study uses two different bearings, namely a normal bearing and a faulty bearing. Fault on the bearing were made by Electrical Discharge Machine (EDM) on the inner race with a width of $0.4 \mathrm{~mm}$ and a depth of $1.4 \mathrm{~mm}$. The test is carried out on an industrial fan test rig and recorded using MATLAB. The vibration signal is recorded to result of 700 files for each bearing condition. The vibration data is subsequently extracted into 17 statistical parameters which are then visually selected as input of SVM classifier. The SVM classifiear is trained using variations of the Radial Basis Function (RBF), Polynomial and Linear kernels. The results shows that the statistical parameters of entropy-standard error using variation of the RBF, Polynomial and Linear kernels gives the highest accuracy of $100 \%$.

Keywords: kernel function, pattern recognition, spectrum, statistical parameters 


\section{PENDAHULUAN}

Di dunia industri, perawatan sangat dibutuhkan untuk mengetahui masalah-masalah secara dini dan akurat. Salah satu metode yang digunakan untuk perawatan adalah breakdown maintenance, dimana perawatan dilakukan setelah terjadi kerusakan. Breakdown maintenance tidak bisa memprediksi kapan komponen mesin akan terjadi kerusakan, oleh karena itu pemilik industri menggunakan perawatan jenis Predictive Maintenance (Latuny, 2013). Kelebihan metode Predictive Maintenance adalah dapat mengetahui kerusakan dan dapat mengurangi kerugian dari berhentinya mesin secara tiba-tiba yang dapat mengganggu proses produksi (Susilo, 2009). Predictive Maintenance adalah kegiatan perawatan yang dilakukan dengan cara mengalisa kondisi mesin sebelum terjadi kerusakan. Analisis vibrasi merupakan metode yang digunakan pada Predictive Maintenance untuk menganalisis komponen mesin yang menghasilkan getaran. Fan adalah salah satu mesin yang banyak digunakan di dunia industri yang berfungsi untuk mengeluarkan udara di dalam ruangan ke keluar ruangan dan menjaga sirkulasi udara didalam ruangan. Salah satu komponen penting dari fan adalah bantalan.

Bantalan adalah komponen dari fan yang berfungsi untuk menahan beban poros, serta dirancang untuk menerima beban aksial dan radial, salah satu jenis bantalan yang sering digunakan pada bantalan adalah jenis ball bearing yang memiliki kelebihan yaitu minim gesekan dibanding jenis lainnya. kerusakan pada bantalan bola ditunjukkan oleh adanya getaran dengan frekuensi tertentu yang muncul, sedangkan tingkat kerusakan pada umumnya diketahui dari besarnya amplitudo getarannya (Suhardjono, 2005). Ada beberapa metode yang banyak digunakan untuk mendeteksi kerusakan pada bantalan diantaranya metode berbasis getaran seperti spektrum dan envelope. Spektrum adalah cara untuk mendeteksi kerusakan bantalan dengan metode berbasis getaran (Setyawan dkk, 2018). Menurut Kamiel dkk. (2017) metode spektrum tidak selalu dapat mendeteksi secara jelas amplitudo frekuensi cacat bantalan. Oleh karena itu digunakan metode envelope, dimana metode envelope adalah penyempurnaan dari metode spektrum dengan cara menghilangkan amplitudo tinggi di frekuensi rendah menggunakan high-pass filter (Scheffer dan Girdhar, 2004). Kamiel dkk. (2017) mendeteksi cacat pada bantalan bola pompa sentrifugal dengan menggunakan metode analisis spektrum frekuensi dan spektrum envelope. Hasil penelitian ini mengkonfirmasi hasil dari penelitian sebelumnya oleh Tiwari dkk. (2013), dimana spektrum envelope memberikan hasil yang superior dibandingkan spektrum. Selain metode berbasis spektrum, metode berbasis pengenalan pola (pattern recognition) dapat digunakan untuk mendeteksi cacat bantalan. Salah satu jenis algoritmanya yang banyak digunakan adalah Support Vector Machine (SVM).

SVM berusaha menemukan hyperplane terbaik yang bisa memisahkan dua kelas yang berbeda (Vapnik, 1999). Amandi. (2015) melakukan penelitian tentang diagnosis cacat pada bantalan gelinding dengan metode SVM yang menggunakan tiga kernel sebagai fungsi dasar yaitu kernel RBF, linear dan polynomial. Hasil klasifikasi didapatkan akurasi diatas 95\%. Menurut Suwarmin dkk, (2017) metode SVM yang digunakan untuk mengidentifikasi keausan pada bantalan tirus (tapered bearing) menggunakan metode $K$-fold $=10$ menghasilkan keakurasian tinggi yaitu $83 \%$. Sukendi dkk. (2015) menggunakan SVM untuk mendeteksi cacat dini pada bantalan dan menyimpulkan bahwa akurasi klasifikasi berbanding lurus dengan jumlah data training.

Dari hasil penelitian diatas, analisis berbasis spektrum dapat mendeteksi cacat bantalan dengan baik namun relatif sulit dipahami oleh operator di lapangan. SVM adalah metode klasifikasi berbasis pengenalan pola yang lebih mudah digunakan operator di lapangan dalam mendeteksi cacat bantalan karena tidak perlu menterjemahkan grafik spektrum. Penelitian ini bertujuan mendeteksi cacat lintasan dalam pada bantalan bola sebuah fan industri menggunakan algoritma SVM.

\section{Metode Penelitian}

Sinyal getaran bantalan pada fan diambil pada sebuah rig uji dengan dua kondisi bantalan yaitu bantalan bola normal (tanpa cacat) dapat dilihat pada Gambar 1 (a) dan bantalan cacat (rusak) dapat dilihat pada Gambar 1 (b). Cacat pada bantalan dibuat menggunakan electrical discharge machine (EDM) pada lintasan dalam dengan lebar 0,4 $\mathrm{mm}$ dan kedalaman 1,4 $\mathrm{mm}$ 


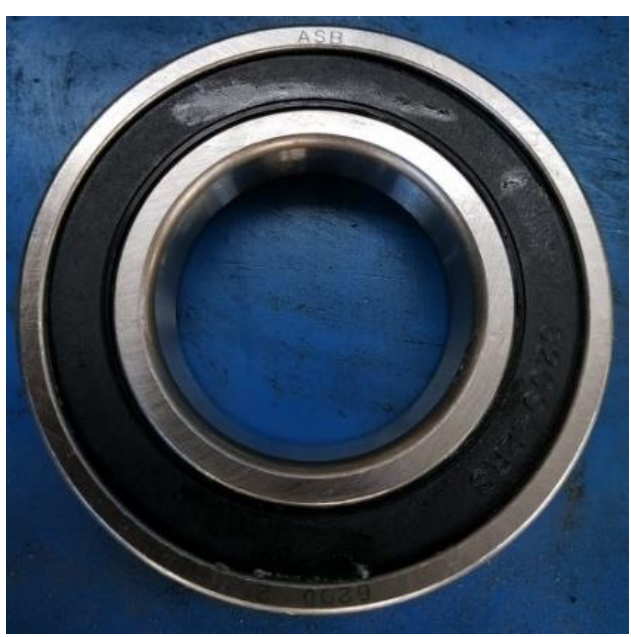

(a)

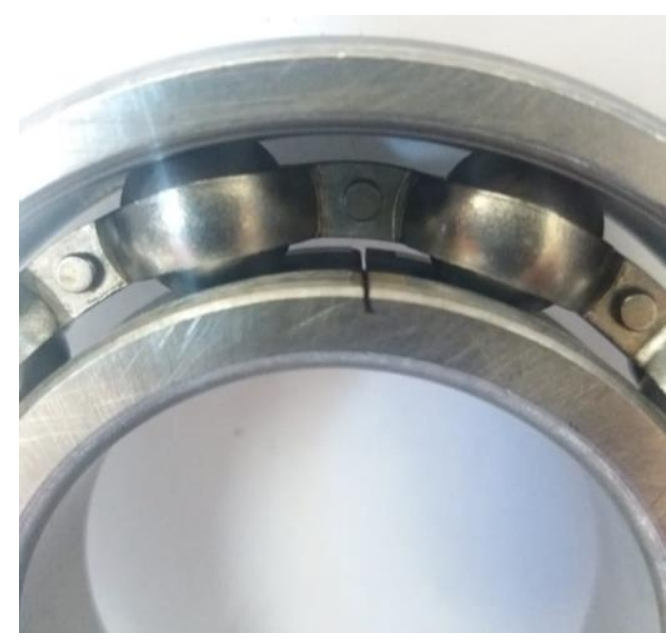

(b)

GAMBAR 1. (a) Bantalan normal dan (b) bantalan cacat

Rig uji terdiri dari beberapa komponen yaitu fan, poros, bantalan, motor, roda gigi, puli, dan sabuk. Motor listrik memutar pasangan roda gigi dan meneruskan torsi ke pasangan sabukpuli yang kemudian memutar fan melalui sebuah poros. Gambar skematik rig uji ditunjukkan pada Gambar 2.

Sinyal getaran masing-masing kondisi bantalan direkam oleh sebuah akselerometer yang diletakkan di atas rumah bantalan yang dekat dengan puli. Sampling rate adalah sebesar $17066 \mathrm{~Hz}$. Akuisisi sinyal getaran dilakukan sebanyak 700 file data untuk masing-masing kondisi bantalan yang setiap filenya berdurasi rekaman 10 detik; terdapat jeda 2 detik di antara rekaman dua potong data. Tujuh ratus data diektraksi ke 17 parameter statistik yaitu Standard Deviation (SD), Root Mean Square (RMS), Crest Factor, Variance, Mean, Entropy, Minimum Value, Standard Error (SE), Skewness, Maximum Value, Range, Sum, Median, Signal to Noise and Distortion Ratio (SINAD), Peak Value, Kurtosis dan Signal to Noise Ratio (SNR). Hasil plot dari 17 parameter tersebut diseleksi secara visual dan dipilih yang dapat memisahkan kedua kelas dengan baik. Lima ratus data digunakan untuk proses training dan 200 data digunakan untuk proses testing.

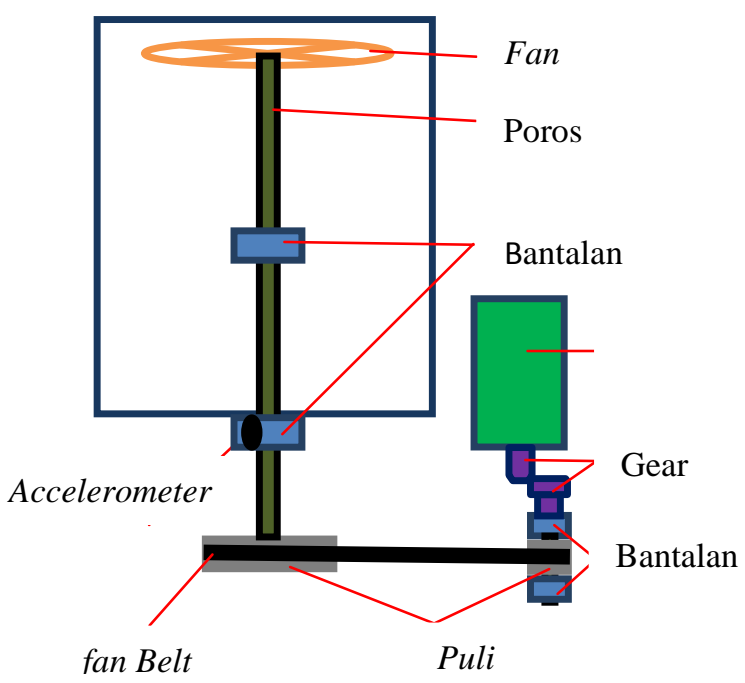

GAMBAR 2. Skema rig uji fan industri 


\section{HASIL DAN PEMBAHASAN}

Gambar 3 (a) adalah plot sinyal getaran domain waktu bantalan normal. Dengan amplitude maksimal 3,526 mV sedangkan pada Gambar 3 (b) adalah plot sinyal getaran domain waktu bantalan cacat dengan amplitudo maksimal $9.525 \mathrm{mV}$. Kenaikan amplitudo disebabkan impak antara lokasi cacat dengan elemen bantalan. Walaupun kenaikan amplitudo terlihat signifikan namun penyebab kenaikan tersebut tidak dapat dipastikan karena cacat bantalan. Gambar 4 menunjukkan hasil plot dari 17 parameter statistik. Metode yang digunakan untuk memilih parameter statistik adalah seleksi visual, yaitu menggolongkan parameter statistik yang dapat memisahkan dua kondisi tanpa tumpang tindih (overlap) dengan yang terdapat tumpang tindih data. Hasil seleksi dari 17 parameter dapat dilihat pada Tabel 1.

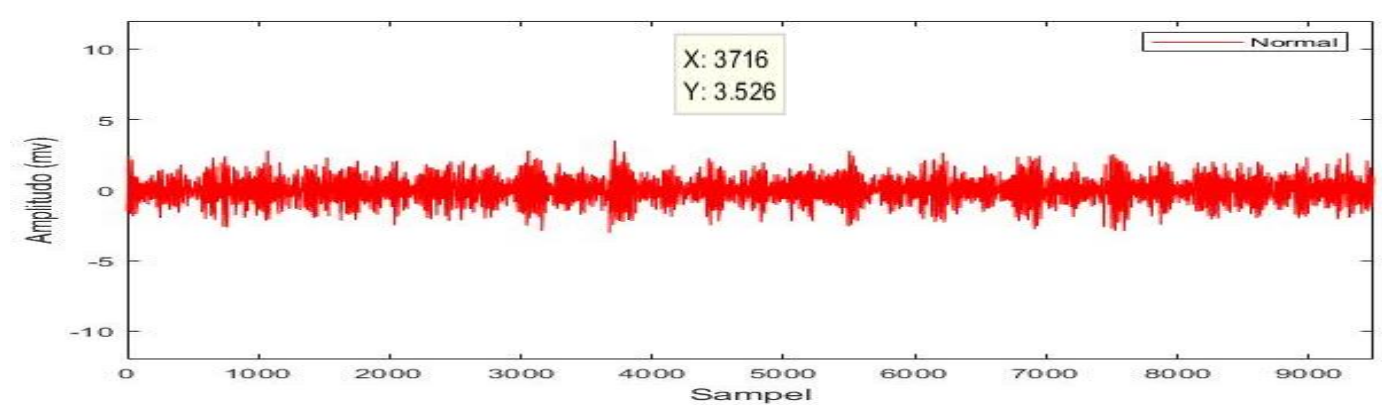

(a)

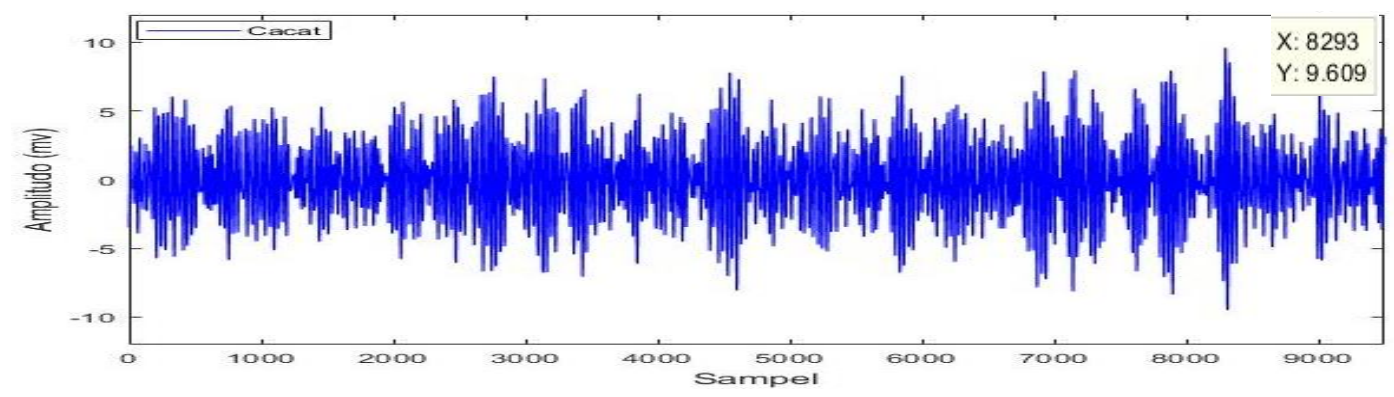

(b)

GAMBAR 3 (a) sinyal getaran normal dan (b) sinyal getaran cacat dalam domain waktu
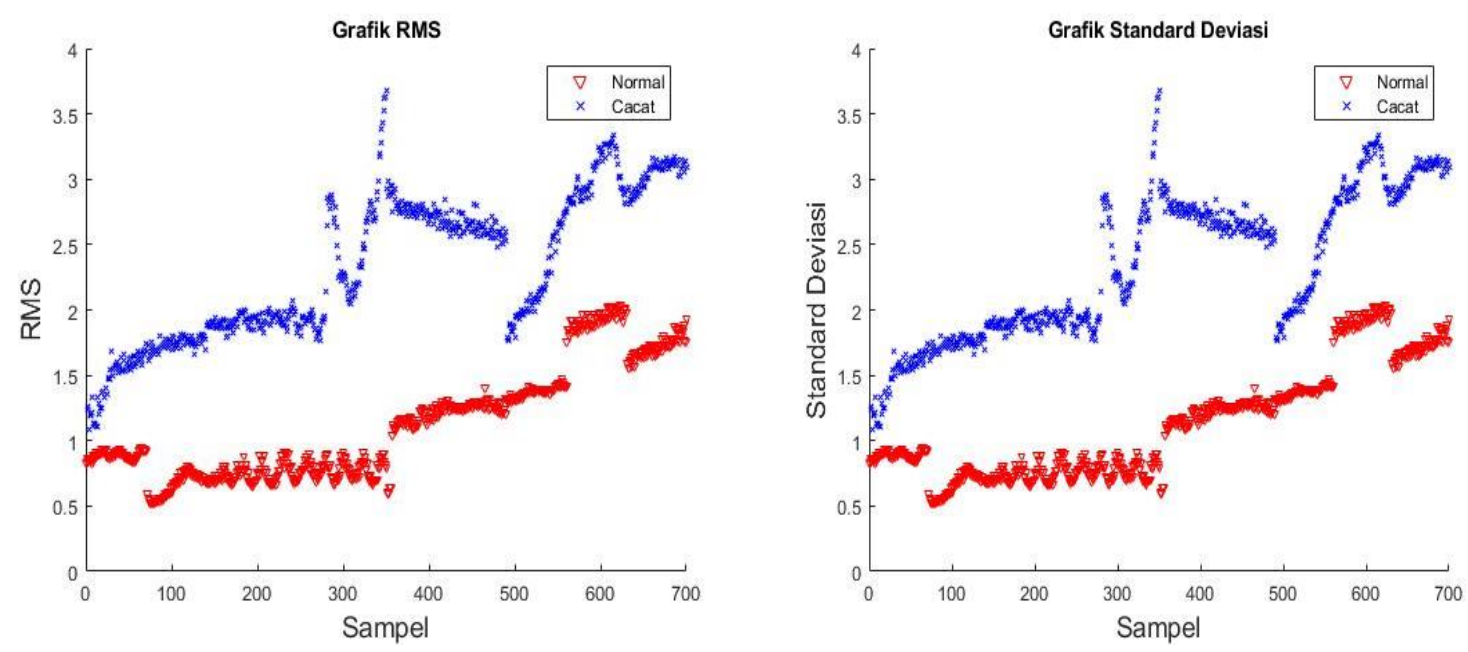

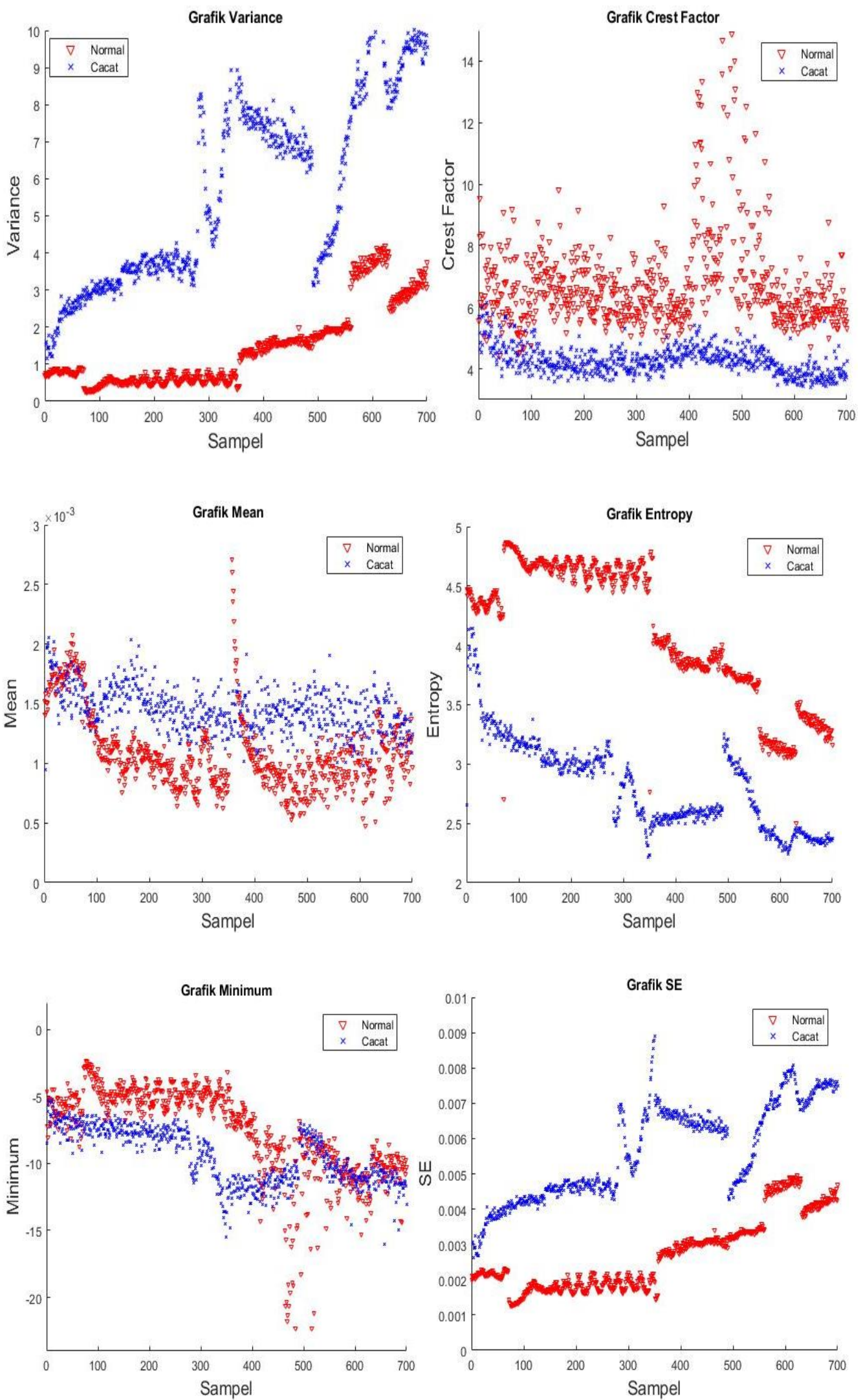

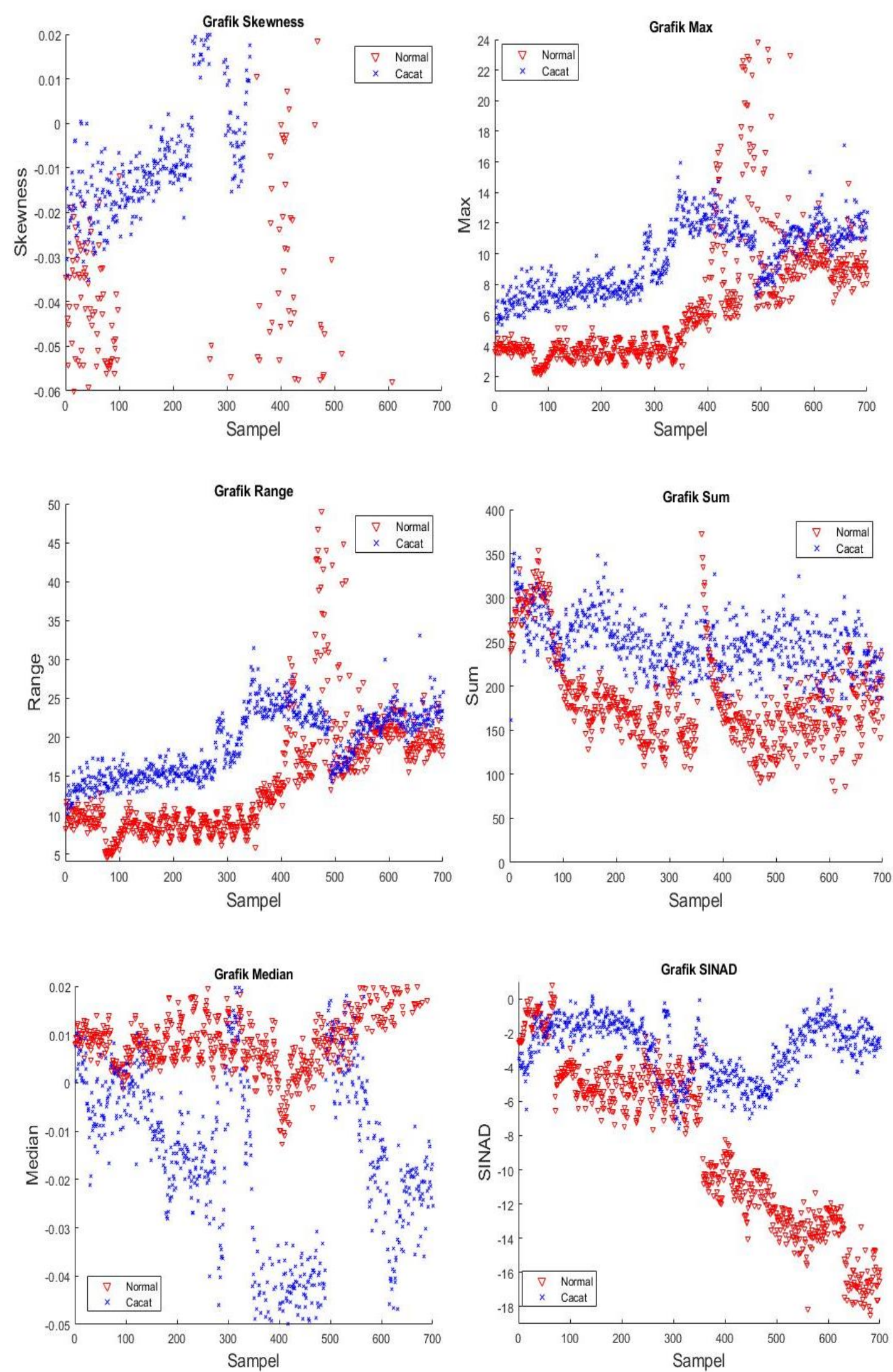

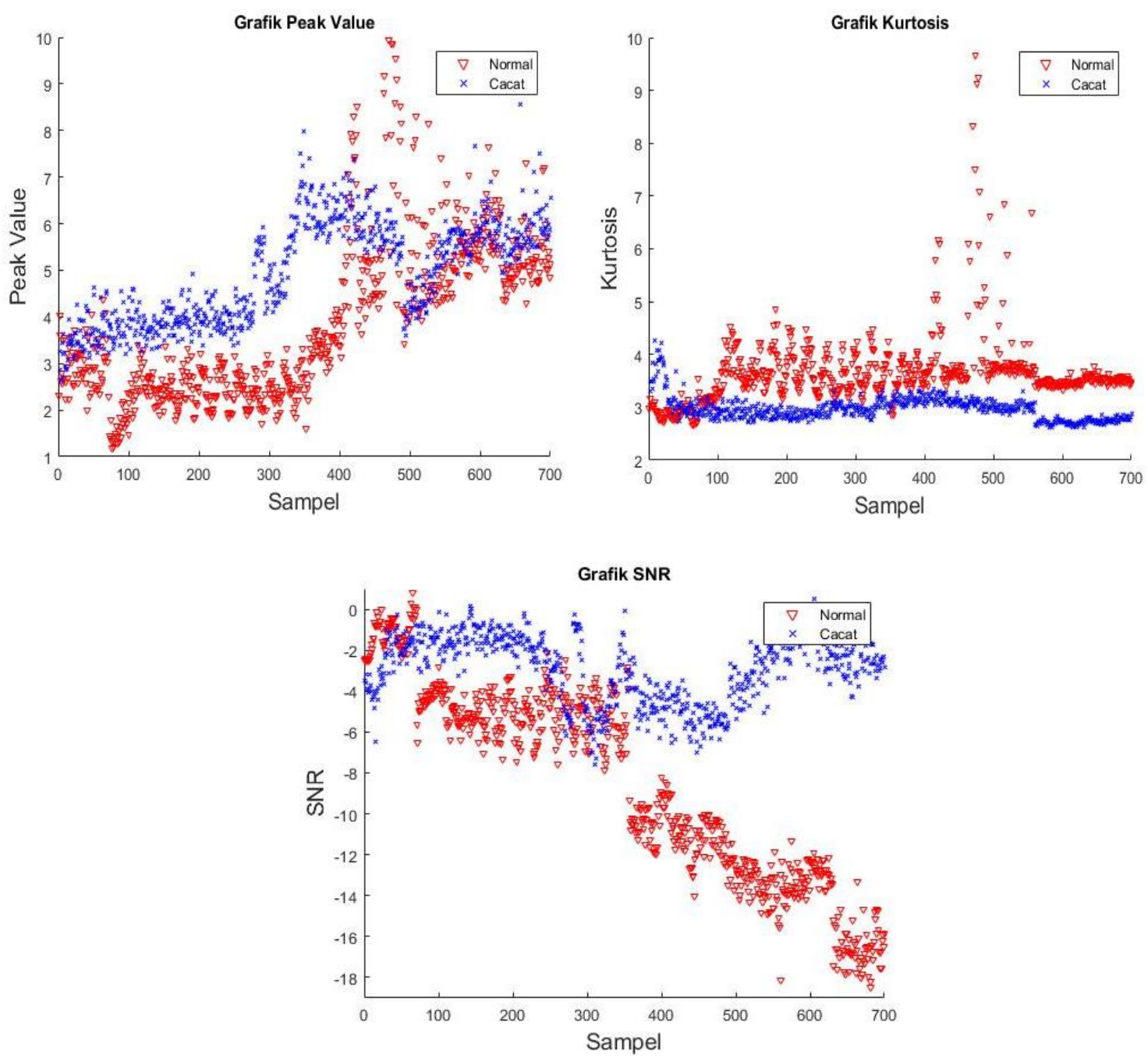

GAMBAR 4. Parameter statistik domain waktu

TABEL 1. Hasil analisa parameter statistic

\begin{tabular}{cc}
\hline Parameter Statistik & Hasil Analisa Parameter \\
\hline RMS, Standar Deviasi, Variance, Entropy, & $\begin{array}{c}\text { Dapat memisahkan sinyal getaran bantalan normal } \\
\text { dengan sinyal getaran bantalan cacat lintasan } \\
\text { dalam dengan baik }\end{array}$ \\
Peak Value, Kurtosis, Crest Factor, & Terdapat tumpang tindih antara sinyal getaran \\
Minimum, Skewness, Median, SINAD, & batanlan normal dengan sinyal getaran bantalan \\
Maximum, Range, Mean, SUM, SNR & cacat \\
\hline
\end{tabular}

Hasil seleksi menunjukkan lima buah parameter statistik dapat memisahkan dua kondisi sinyal getaran dengan baik (tidak ada tumpang tindih), sedangkan dua belas lainnya menghasilkan plot data yang tumpang tindih. Kombinasi dua dari lima parameter statistik tersebut selanjutnya digunakan sebagai input untuk melatih (training) classifier SVM menggunakan tiga buah kernel yaitu radial basis function (RBF), polinomial dan linear. Kombinasi parameter yang dipakai adalah standard error-entropy, variance-standard deviasi dan standard deviasi-RMS. Proses training adalah proses pembentukan classifier. Proses ini menghasilkan model berupa support vector yang akurasinya diuji menggunakan data testing. 
Gambar 5(a) adalah plot hasil training classifier SVM dengan menggunakan parameter statistik standart error-entropy sedangkan Gambar 5(b) adalah plot hasil data testing terhadap classifier SVM yang menunjukkan pemisahan nyata antara dua kelas. Classifier SVM dapat memisahkan kelas dengan optimal tanpa terlihat data dari dua kelas saling tumpang tindih.. Pada dasarnya Gambar 5(b) memiliki pola yang sama dengan Gambar 5(a) karena pada proses testing SVM tidak membentuk model baru melainkan menempati model yang telah dibentuk pada proses training. Pada penelitian sebelumnya yang dilakukan oleh Rapur dkk. (2016) dengan parameter stastistik entropy dengan standart error juga membuktikan bahwa kedua parameter tersebut dapat memisahkan dua kelas dengan baik.

Gambar 6(a) adalah plot hasil training dengan menggunakan parameter standart deviasivariance sedangkan Gambar 6(b) adalah plot hasil testing. Gambar 6(b) menunjukkan classifer SVM dapat memisahkan dua kelas dengan nyata walaupun marginnya sangat kecil yang berpotensi terjadi salah klasifikasi jika data yang diterima diganggu oleh noise yang ditunjukkan oleh nilai SNR yang rendah. Hasil ini sesuai dengan penelitian yang dilakukan oleh Rapur dkk. (2016) yang menyatakan bahwa parameter statistik standar deviasi-

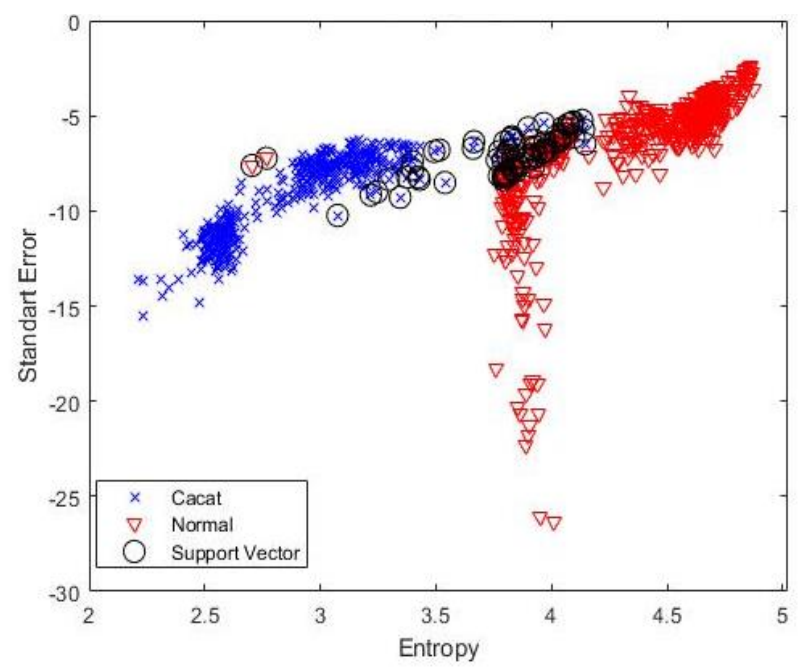

variance akurat untuk mengklasifikasi cacat pada bantalan.

Gambar 7(a) adalah plot training classifier dengan menggunakan parameter statistik RMSstandar deviasi sedangkan Gambar 7(b) adalah plot hasil testing. Gambar 7(b) menunjukkan pemisahan antara dua kelas dengan margin yang sangat kecil dan teramati data dari dua kelas yang tumpang tindih. Penelitian yang dilakukan oleh Fathurrohman dkk. (2017) menunjukkan parameter stastistik RMSstandar deviasi dapat memisahkan dua kelas dengan baik. Hasil tersebut tidak sejalan dengan hasil yang diperoleh pada penelitian ini dimana margin antara dua kelas yang sangat kecil dan terjadi tumpang tindih data. Hal ini disebabkan oleh nilai covariance yang tinggi antara dua parameter yang mengakibatkan hubungan linear yang kuat sehingga konten informasi dua parameter tersebut pada dasarnya identik sehingga kemampuan memisahkan dua kelas tidak efektif.

Tabel 2 menunjukkan hasil akurasi penggunakan Kernel Fuction seperti Radial Basis Function (RBF), Polynomial dan Linear. Nilai ini diukur berdasarkan bagaimana set data yang digunakan dalam proses testing dapat menempati posisinya sesuai penggolongan kelas yang ada pada model klasifikasi. Semakin banyak data yang berada di dalam kelasnya maka tingkat akurasi klasifikasi semakin besar

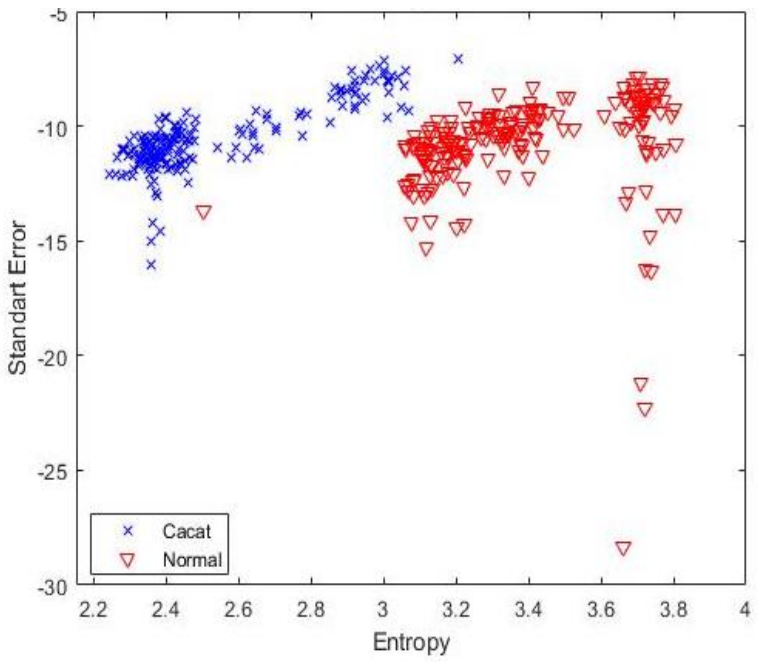

GAMBAR 5(a) Training data normal dan cacat (b) Hasil testing data normal dan cacat 

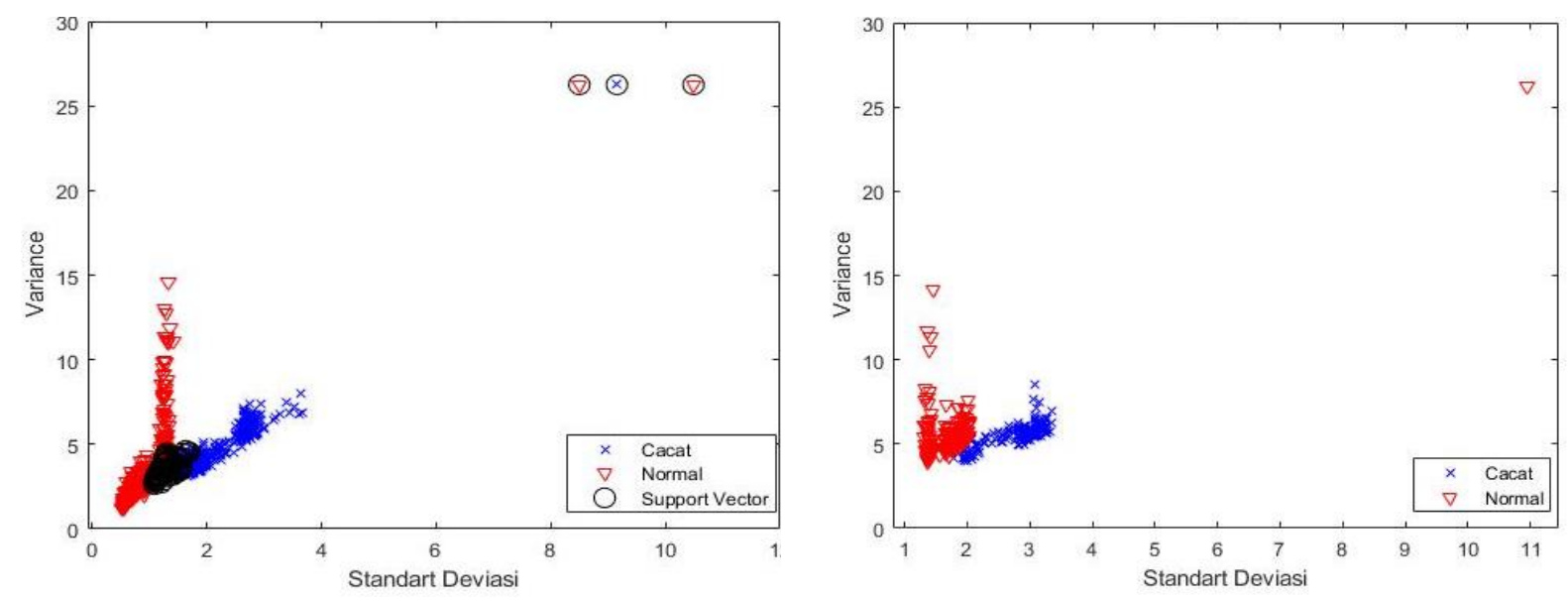

GAMBAR 6(a) Training data normal dan cacat (b) Hasil testing data normal dan cacat
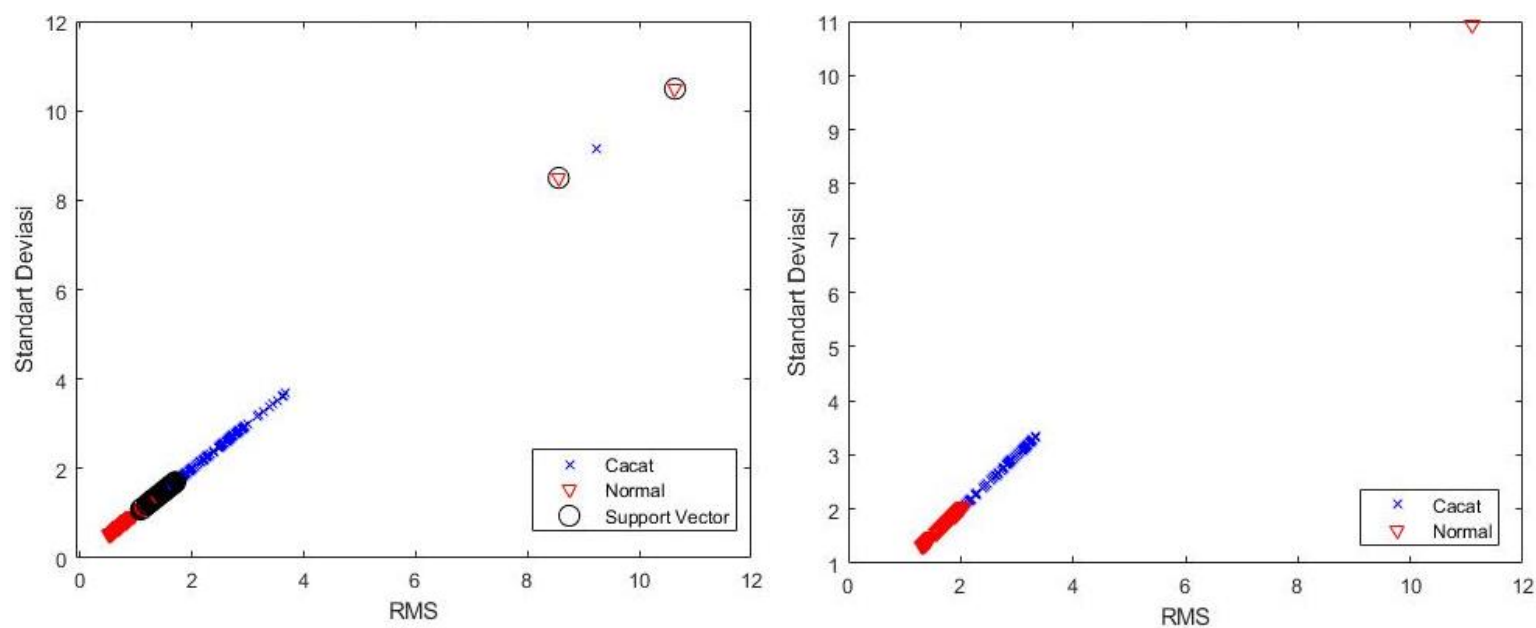

GAMBAR 7(a) Training data normal dan cacat (b) Hasil testing data normal dan cacat

TABEL 2. Hasil tingkat akurasi dari kombinasi parameter dengan fungsi kernel

\begin{tabular}{|c|c|c|c|c|}
\hline No & $\begin{array}{c}\text { Kombinasi Parameter } \\
\text { Statistik }\end{array}$ & $\begin{array}{c}\text { Akurasi } \\
\text { Kernel Linear }\end{array}$ & $\begin{array}{c}\text { Akurasi } \\
\text { Kernel RBF }\end{array}$ & $\begin{array}{c}\text { Akurasi Kernel } \\
\text { Polynomial }\end{array}$ \\
\hline 1 & Entropy dengan Standart Error & $100 \%$ & $100 \%$ & $100 \%$ \\
\hline 2 & $\begin{array}{c}\text { Standart Deviasi dengan } \\
\text { Variance }\end{array}$ & $99,75 \%$ & $100 \%$ & $100 \%$ \\
\hline 3 & RMS dengan Standart Deviasi & $99,50 \%$ & $99,25 \%$ & $99,50 \%$ \\
\hline
\end{tabular}

\section{KESIMPULAN}

Metode Support Vector Machine (SVM) berhasil mendeteksi cacat lintasan luar bantalan bola dengan menggunakan variasi tiga buah kernel dimana kombinasi parameter statistik entropy-standard error memberikan akurasi tertinggi yaitu $100 \%$.

Setiap parameter statistik domain waktu menghasilkan karakteristik dan informasi spesifik terhadap distribusi data sinyal vibrasi, yaitu: RMS, SD, Variance, Entropy, dan SE dapat memisahkan kelas dengan baik. Peak value, kurtosis, crest factor, mean, skewness, maximum value, minimum value, range, sum, median, signal to noise and distortion ratio (SINAD), dan signal to noise ratio (SNR) terjadi tumpang tindih data.

\section{UCAPAN TERIMA KASIH}

Penulis mengucapkan terima kasih kepada Irawan, Fahri, Wildan, Iwan, dan Agus yang telah membantu dalam penelitian ini. 


\section{DAFTAR PUSTAKA}

Adi, F., \& Suwarmin. (2017). Identifikasi Keausan Bantalan Tirus (Tapered Bearing) Berbasis Analisis Vibrasi dengan Metode Support Vector Machine. Jurnal Teknik ITS, 768-771.

Amandi, D. N. (2015). Diagnosis Kerusakan pada Bantalan Gelinding dengan Metode Support Vector Machine. AGRI-TEK, 62-73.

Fathurrohman, M. (2017). Diagnosa Kerusakan Bantalan Bola Menggunakan Metode Support Vector Machine. Jurnal Mekanika, 14-21.

Kamiel, B. P., \& Ramadhan, R. S. (2017). Pengaruh Kecepatan Operasi Pompa Sentrifugal Terhadap Sensitifitas Metode Deteksi Fenomena Kavitasi Berbasis Parameter Statistik Domain Waktu. Semesta Teknika, XX(1),51-66.

Kamiel, B. P., Mulyani, \& Sunardi. (2017). Deteksi Cacat Bantalan Bola Pada Pompa Sentrifugal Menggunakan Spektrum Getaran. Semesta Teknika, Vol. 20, No.2, 204-215.

Latuny, J. (2013). A Sensitivity Comparison of Neuro-fuzzy Feature Extraction Methods from Bearing Failure Signals. 253-256.

Rapur, J. S. (2016). Experimental Time-domain Vibration Based Fault Diagnosis of Centrifugal Pumps using SVM. ASCEASME Journal of Risk and Uncertainty in Engineering Systems, Part B: Mechanical Engineering.

Scheffer, C., \& Girdhar, P. (2004). Practical Machinary Vibration Analysis and Predictive Maintenance. Burlington: Elsevier Ltd.

Setyawan, H. P., \& Suryadi, D. (2018). Analisis Karakteristik Vibrasi pada Paper Dryer Machine untuk Deteksi Dini Kerusakan Spherical Roller Bearing. ROTASI, 110-117.

Suhardjono. (2005). Analisis Sinyal Getaran Untuk Menentukan Jenis dan Tingkat Kerusakan Bantalan Bola (Ball Bearing). Jurnal Teknik Mesin, Vol. 7, No. 1.
Sukendi,Ikhwansyah, I., \& Suherman. (2015). Analisa Karakteristik Getaran dan Machine Learning Untuk Deteksi Dini Kerusakan Bearing. Jurnal Penelitian Widya Teknika, Vol-23 No.23 Hal 4149.

Susilo, D. D. (2008). Deteksi Kerusakan Bantalan Gelinding Pada Pompa Sentrifugal Dengan Analisis Sinyal Getaran. Jurnal Mekanika, Vol. 7 No. 1.

Tiwari, A., \& Jatola, R. (2013). Fault Detection in Bearing Using Envelope Analysis. Indian Journal of Research, Vol. 3. No. 5.

Vapnik, V. (1995). The Nature of Statistical Learning Theory. New York: Springer Verlag.

PENULIS:

\section{Berli P Kamiel}

Program Studi Teknik Mesin, Fakultas Teknik, Universitas Muhammadiyah Yogyakarta, Jalan Brawijaya, Tamantirto, Kasihan, Bantul, Yogyakarta.

Email : berlikamiel@umy.ac.id

Arie Joko Wiranto

Program Studi Teknik Mesin, Fakultas Teknik, Universitas Muhammadiyah Yogyakarta, Jalan Brawijaya, Tamantirto, Kasihan, Bantul, Yogyakarta.

Email : ariejokowiranto@gmail.com

Bambang Riyanta

Program Studi Teknik Mesin, Fakultas Teknik, Universitas Muhammadiyah Yogyakarta, Jalan Brawijaya, Tamantirto, Kasihan, Bantul, Yogyakarta.

Email: bambangriyanta@umy.ac.id

Sulis Yulianto

Program Studi Teknik Mesin, Fakultas Teknik, Universitas Muhammadiyah Jakarta, Jalan Cempaka Putih Tengah 27, Jakarta

Email: Email: sulis.yulianto@ftumj.ac.id 